Archives of Agriculture and Environmental Science

\title{
Value chain analysis of Allo (Girardinia diversifolia) in Solukhumbu district of Nepal
}

\author{
Padam Lal Bhandari \\ Agriculture and Forestry University, Rampur, Chitwan, NEPAL \\ E-mail: padam977@gmail.com
}

\section{ARTICLE HISTORY}

Received: 26 September 2019

Revised received: 27 October 2019

Accepted: 16 November 2019

\section{Keywords}

Allo

Fiber

Natural resources

Perennial shrub

Value chain

\begin{abstract}
Allo (Girardinia diversifolia) is a herbaceous perennial shrub found in subtropical and temperate regions of Nepal. The stem bark of Allo contains fibers with unique strength, smoothness, and silk-like luster. The fiber is used to make clothing since times immemorial. The fiber, thread, and woven clothes are commercially traded in a few districts of Nepal. Residents of hilly areas and ethnic groups have for centuries extracted and spun the fiber to weave durable jackets, porter headbands or straps, fishing nets, ropes, bags, mats, coarse clothing material, and blankets. Therefore, this study was conducted in Solukhombu district using focus group discussion, key informant interview with Allo collectors, and the rapid market survey was conducted with Allo processing enterprises as well as traders at regional to national market hubs in 2018. We found that the exploitation rate of Allo in the study area has been affecting the availability and sustainability of raw material in the natural habitat. This study suggested the need for sustainable management through domestication and proper harvesting technique.
\end{abstract}

(C)2019 Agriculture and Environmental Science Academy

Citation of this article: Bhandari, P.L. (2019). Value chain analysis of Allo (Girardinia diversifolia) in Solukhumbu district of Nepal. Archives of Agriculture and Environmental Science, 4(4): 410-423, https://dx.doi.org/10.26832/24566632.2019.040407

\section{INTRODUCTION}

Allo (Girardinia diversifolia) based enterprise is a suitable business to create employment at the local level and reduce poverty in the hilly region of Nepal. There are enough resources in the local forest, many Allo based products are produced at the local level for personal use, and finished goods (at least clothes) are traded overseas. However, there is no authentic government database regarding production and trade. Nepal produces around 1,805 tons of Allo thread per year (MEDEP, 2010). Half of the production is consumed within Nepal whereas the rest is exported. The demand for Allo weaved clothes are high in the international market and it is a prime souvenir product of Nepal. Allo is widely distributed in the southern belt of the Himalayas. It has been recorded in Northern Pakistan, Kashmir, North-west India, Nepal, Sikkim, Bhutan, Southern and Eastern Tibet, Sri Lanka, Northern Myanmar, China, and Malaysia. It is distributed throughout Nepal at altitudes between 1200 to $3000 \mathrm{~m}$ in moist, forest areas with semi- or no shades, along streams and tributaries, and on the edges of cultivated land (Polunin and Stainton, 1984).
There was no authentic resource inventory of Allo bark in Solukhumbu district. In most of the Rural Municipalities and Municipalities, there is a huge potentiality for harvesting, domestication, and establishment of Allo based enterprises. Mahakulung Rural Municipality-3, Cheskam is popular for doing Allo based enterprises. Annual Allo bark collection trends in Solukhumbu is estimated to be 15 tonnes per year. On the other hand, around $70 \%$ of raw materials are harvested from private land. From this scenario, we can assume that through the mobilization of local people, raw materials can be managed more through domestication in community forest and private land. During the field study, it was found that tentative $50 \%$ of dried Allo bark was being traded in adjoining district Sankhuwasabha. From the remaining $7500 \mathrm{~kg}$, Allo bark; $3700 \mathrm{~kg}$ Allo fiber was produced in Solukhumbu. Around $1500 \mathrm{~kg}$ Allo fiber was traded in the Sankhuwasabha district (Paudel and Rosset, 1988). Tentative $2048 \mathrm{~kg}$ Allo thread was produced and tentative $1000 \mathrm{~kg}$ was utilized for the production of Allo cloth in Solukhumbu district. Through this activity, 63 local people have been getting employment opportunities at the local level and tentative trade value is NPR 6.59 million. If we could support the local communities to 
produce cloth from all collected Allo bark; tentative 136 local people will get employment opportunities and trade value will reach NPR 1.44 million per year (Ojha et al., 2000). In the present context of Solukhumbu district, consumer products made out of Allo such as bag, hat, cap, shoes, etc. are supplied from Kathmandu (after sending Allo cloth to Kathmandu and return as consumer goods) because of lack of skilled human resource (HR) at local level. There is another possibility to increase employment opportunities through support in technical and other aspects of the production of consumer goods at the local level (Pyakurel and Baniya, 2011).

Allo based enterprises are labor-intensive businesses. This could help to create employment opportunities at the local level and can utilize unused local resources. Through yearly sustainable harvesting, it would not hamper the regeneration of production. In this business, mostly women and DAG have been involved in harvesting, value addition, and trade. In the context of PAF, there are more than 1,136 members directly or indirectly involved in this business from different districts. There is a need for support to prepare a business plan and access to financial services from financial institutions. Likewise, support is required to include it in the operational plan of the CFUG/Buffer zone CFUG for the sustainable management of Allo. Inventory of resources should be taken for assessment of yearly production potential in a sustainable manner. Support is required to make technology and management accessible in order to reduce the cost of production especially for thread making and cloth production. It is necessary to organize skill training and support basic infrastructure at the local level from the cloth industry in coordination with different levels of government and private sectors. To expand business on a commercial scale, it is necessary to encourage and support MEs to produce value-added products and apply new technology to reduce the cost of production. Likewise, research and development are necessary to introduce new technology to reduce the cost of production and improve quality. In the marketing sector, the M4P mechanism should be applied for assurance of the market. There should be regular interaction between market actors including producers to increase market access and produce market demanded products. The following are key objectives to conduct VCA of Allo: To prepare a value chain map and business plan with a special focus on alliance and financing with different actors in the forward and backward linkage. To analyze potentiality of income generation, employment creation, willingness to pay fee/ commission and involvement of private sector in value chains of commodity under study, to identify the current status and gap of the value chain (technology, policy, market, skill/ knowledge, and accessibility) including constraints and opportunities (SWOT) of the commodities under study. To identify the factors affecting the competitiveness of the product produced under PAF pockets, peri-urban and JSDF funded activities, and potentiality for import substitution and/or export promotion. Identify the involved producer groups/CFUGs, areas and potentiality to expand through the mobilization of existing and additional households.

\section{MATERIALS AND METHODS}

\section{Methodology and data collection}

Both quantitative and qualitative methodologies were used to collect necessary information from value chain actors and enablers at a different stage of the chain of each commodity and were analyzed. A comprehensive value chain analysis of the Allo from Poverty Alleviation Fund (PAF) beneficiaries of the Solukhumbu district of Nepal have been involved directly or indirectly. There are 603 local community organization members who are involved in Allo enterprises. Questionnaires and checklists were developed and used for all value chain actors, enablers including inputs suppliers, producers, collectors, processors, wholesalers and retailers in value chain function. In this context, this study was conducted in Solukhombu district using focus group discussion, key informant interview with Allo collectors, and the rapid market survey was conducted with Allo processing enterprises as well as traders at regional to national market hubs in 2018.

In addition, value chain development (VCD) alliance and financing detail checklist were used to pocket products community organization (CO) members, cooperatives, BFIs, and banks. Two FGDs were conducted in Solukhumbu. Cost-benefit analysis, business potential, gap, and stakeholder analysis, value chain mapping, end market assessment, product, chain, function and process diversifications, potential value chain development alliance and financing models and intervention were assessed in this study. Furthermore, both backward and forward linkage and horizontal and vertical integration of each commodity were judged based on Poverty Alleviation Fund (PAF) Future Strategy, growth and value chain development potential for business promotion in a sustainable manner.

\section{Method of data analysis}

Since chain studies were carried out in Nepal in the past by numerous institutions, desk reviews were also conducted to obtain secondary data to ensure validation as well as to avoid the overlap. Desk review, group discussion (with producers using focus group discussion), key informant interview (with input suppliers, key model farmers, collectors, traders, processors, institutions and other VC market chain actors, enablers), rapid market appraisal (with commodity traders and wholesale market) and case studies were used as a VCA study technique using participatory learning and action (PLA) approach. The SWOT analysis, value chain map, backward and forward linkages with a margin of all the actors in the value chain with recommendation mentioning the bottlenecks, opportunities, key leverage points, and intervention strategy were assessed for each commodity. The Statistical Package for Social Sciences (SPSS) was used to analyze data. Descriptive statistics and value chain analysis tools were used to analyze data.

\section{The approach of data collection}

The study was conducted in collaboration with Ministry of Agriculture, Land Management and Cooperatives, Ministry of 
Industry, Commerce and Supplies, Ministry of Forests and Environment, and MEDEP, other concerned stakeholders/line agencies focusing the core issue in the Agriculture Development Strategy 2015-2035.

\section{RESULTS AND DISCUSSION}

\section{Production and marketing context of Allo}

The trading of Allo begins with the collection of bark from forests and ends with the export of woven fiber. There are three tiers of actors-micro, meso, and macro-level players-in the value chain. At the micro-level, there are collectors, cloth and thread makers, wholesalers and retailers. At the meso level, there are CFUGs, Buffer Zone CFUG, COs, Cooperatives and district level handicraft associations. At the macro and policy level, there are institutions such as the Cottage and Small Industry Development Board (CSIDB), Department of Forests (DoF), Department of National Park and Wild Life (DNPW) and the Ministry of Industry, commerce and supply, which formulate and implement policies. The structured and predetermined role of these major stakeholders and interactions among them influences the value addition and price mechanism of the enterprise.

All the elements in the supply chain are based on local resources. Allo harvesting is a seasonal business. It is started in October and ends in December (Kartik-Mangsir). Allo thread is being traded-in local level and neighboring districts. Likewise, woven clothes are brought to district headquarters, Kathmandu and sold to entrepreneurs or exporters. Entrepreneurs often weave fine clothes in Solukhumbu themselves and sell in the domestic market or export. Likewise, value addition from Allo cloths has been producing mostly in Kathmandu. Therefore, value addition takes place both in urban and rural areas. Income is shared by both rural communities and urban entrepreneurs. The promotion of quality yarn and cloth production has great potential to alleviate rural poverty in the hilly regions of Nepal.

\section{Product forms and respective prices}

Each hectare of Allo yields around $600 \mathrm{~kg}$ of fiber. Fiber is extracted on a commercial scale in some districts. Allo is traded either raw (dry bark), or semi-processed (coarse fiber), thread or in processed form (cloth). The dried bark is traded anywhere between NRP 90 to 100 per kg; coarse fiber between NRP 200 to 240 per kg; and handmade cloth at NRP 500-600 per meter (Table 1).

Allo-lokta: It means bark of Allo plant or bast extracted from the plant.

Table 1. Product form and price trends.

\begin{tabular}{lll}
\hline \multirow{2}{*}{ Product Forms } & \multicolumn{2}{l}{ Grades (NRP/kg) } \\
\cline { 2 - 3 } & A & B \\
\hline Allo-lokta & 100 & 90 \\
Fiber & 240 & 200 \\
Dhago & 600 & 500 \\
\hline
\end{tabular}

(Sources: FGDs, KII and Field Survey, 2018).
Bhuwa: It means cooked, washed and dried form of Allo-lokta.

Dhago: It's spun or final product of Allo processing i.e. Fiber Further, these products are graded as per the quality of the Allo in these product forms. And the prices differ as per the grade of the product forms. Following is the price list of the different grade

\section{Market actors}

Collectors: Collectors here refer to those people who collect the Allo-lokta (Allo-bark) from the forest. Collectors can also be regarded as the Allo bark extractors. Allo bark is collected from the nearby CF, Buffer Zone Forest and private lands by collectors using traditional weapons such as sickles. They cut down the Allo plant and leave it there for some minutes so that the prickles will not hurt them during bark extraction and transportation. Collectors collect only the bark of the Allo plant leaving the solid, rigid stem making the backpack (Bhari) light for the extraction from the forest to their home. In the context of CF, extraction time is fixed especially from Mangsir to Poush, the CF allows its member to enter the CF for Allo bark. Collectors cut down the Allo bark as much as they can which can extend to one day long. It is observed that a collector cut down or extract up to $20 \mathrm{~kg}$ of Allo bark in one day. The permission is given by CF only after payment of a certain amount by the collectors. Collectors collect the bark to their home and use or sell it as per the market condition. If they have to stock it then they will dry it in the courtyard and store it. However, if they have to produce fiber, they will immediately use it without drying it in sunlight.

Processors/manufacturer/producer: The processors buy the Allo lokta, fiber from the collectors or in some cases collectors themselves form a group and start processing the Allo barks. They process the Allo lokta bought from collectors, produce fiber and they weave out clothes and trade to the local market as well.

Traders: Traders trade clothes prepared by the processors inside as well as the outside district. The most notable matter is that the traders only trade finished Allo products and the processors themselves are traders. The below box shows the different sizes of clothes. The price of Pure Allo cloth was NPR 500 and cost of production was NRP 417 for 26/27 inch*1 meter (30 inch width with $4.5 \mathrm{~m}$ cloth can make 1 coat; $26-27$ inch width with $5 \mathrm{~m}$ cloth can make 1 coat; $26-27$ inch width with $5 \mathrm{~m}$ can make 1 waistcoat; 30 inch width with $1 \mathrm{~m}$ cloth can make 1 waistcoat and 30 inch width with $2 \mathrm{~m}$ cloth can make 1 ZUWARI coat).

Consumers: Most of the consumers are foreigners or tourists. Nowadays domestic consumers are also interested to purchase and use Allo products. Due to a lack of advertisement and knowledge about Allo, the marketing of Allo has not increased the desired level. Most of the Allo products consumers are from Kathmandu and those who visit the district. 


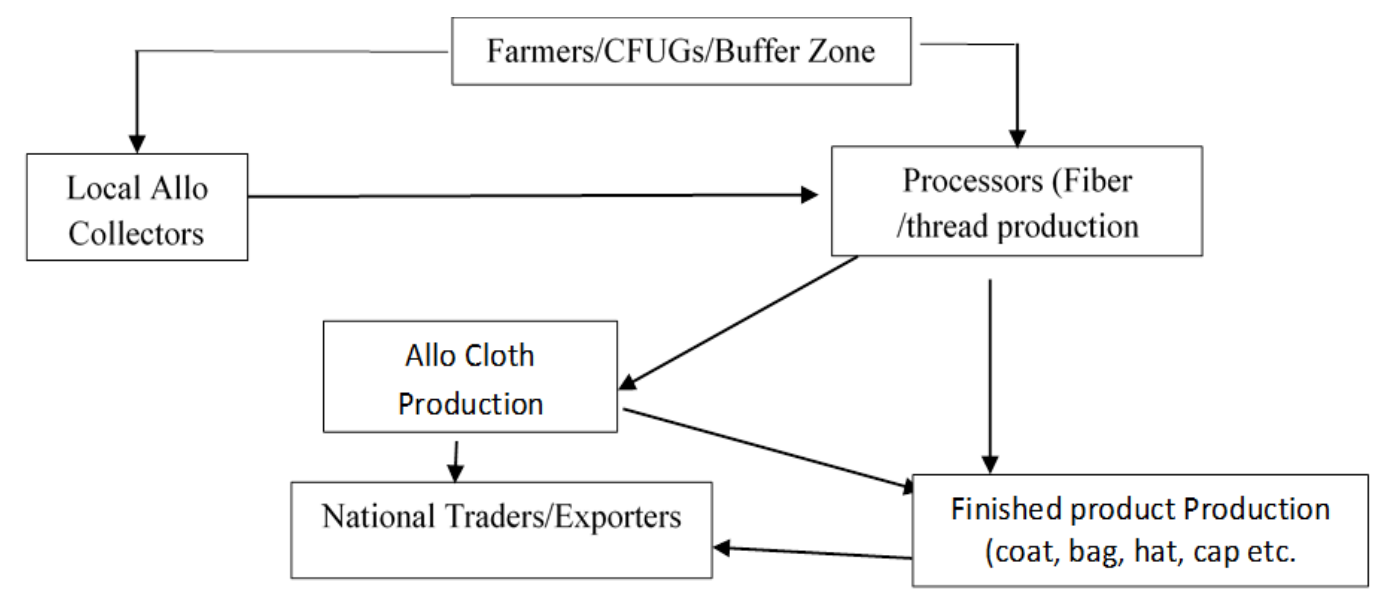

Figure 1. Marketing channels of Allo trade (Source: ECARDS-Nepal/MSFP, 2015).

\section{Distribution of value addition}

Allo-lokta extraction: Allo-lokta (Allo Bark) is extracted from the nearby forest i.e. CF, buffer zone, and private lands. People use local equipment such as sickle to cut down and extract Allo bark from the Allo plants. Allo Lokta is extracted at the forest or private land then only carried home (Figure 1).

Drying: Drying is done only if Allo lokta is to be stocked. Otherwise, Allo lokta is directly cooked for further process. Hence, it depends on market demand and the total quantity of Allo-lokta extracted out from the forest.

Cooking: Allo-lokta is cooked with ash, kamero, or caustic soda according to the accessibility, preference and economic condition of the processors. It is usually used for softening the Allo bark into the fiber. Using caustic soda is preferred to ash or kamero because it softens the Allo bark quickly though it is quite expensive with respect to ash and kamero, which is available freely and easily. Cooking usually takes $1 / 2$ to 1 hour if the appropriate amount of heat is provided but it might take 3 to 4 hrs if the heat is lower than required. However, it totally depends upon the amount of Allo lokta cooked too.

Beating and washing: The cooked bark is cleaned in water by continuously beating it with a wooden mallet. Cleansing requires a lot of water, so it is usually done in streams and tributaries.

Cleansing: The washed bark is mixed with paddy husk or in white clay solution and dried in the sun for 5 to $6 \mathrm{hrs}$. The process softens the fiber and brings extra whiteness. Coarse fiber is cleansed again by repeating the earlier process. Finally, the fiber is separated manually by using Katuwa, a traditionally designed wooden equipment to separate fiber from softened bark.

Spinning: Spinning is either done with a self-constructed hand spindle made of wood or with a spinning wheel. A hand spindle is lower than the wheel but is preferred because it is light to carry and women find it handy and suitable for spinning during their leisure time or during other activities. It takes one man-day to weave threads for $1.5 \mathrm{~kg}$ of fiber. Either the threads are sold to entrepreneurs, or collectors themselves weave them to make coarse clothes.

Weaving: Weaving is done with the (taan) loom (weaving machine). The firmness of the yarn depends largely on the skill of the spinner and also on the quality of the fiber. The yarn thus spun is woven on a backstrap loom (ECARDS-Nepal/MSFP, 2015).

Value chain map of Allo sub-sector

This value chain map is the representation of the Solukhumbu district in Nepal. Some adjustments have been made in this value chain map. During mapping, actors involved in this sector with their respective functions are listed and mapped accordingly. Figure 2 presents the definition of each actor, the flow of products within the chain and the relationship between various actors in the value chain map of the Allo sub-sector.

Functions: Major functions involved in this sector are input supply, production, and local processing, threads making and clothmaking at a local level, domestic trading, making different products and trading local and international markets. Allo has been on use in Nepalese society, especially in Himalayan society for rope and their clothes. At present natural fiber products from Allo are used in making various products like a purse, bag, and various types of cloths. These products are also exported to European and American markets.

Actors: The value chain operators and the operational service providers are included as an actor in the value chain (MOAC, 2011). Those functionaries who are directly involved in the transaction or directly support the actors who are involved in the transaction are the VC actors.

Based on activities performed, the actors are classified as below: 


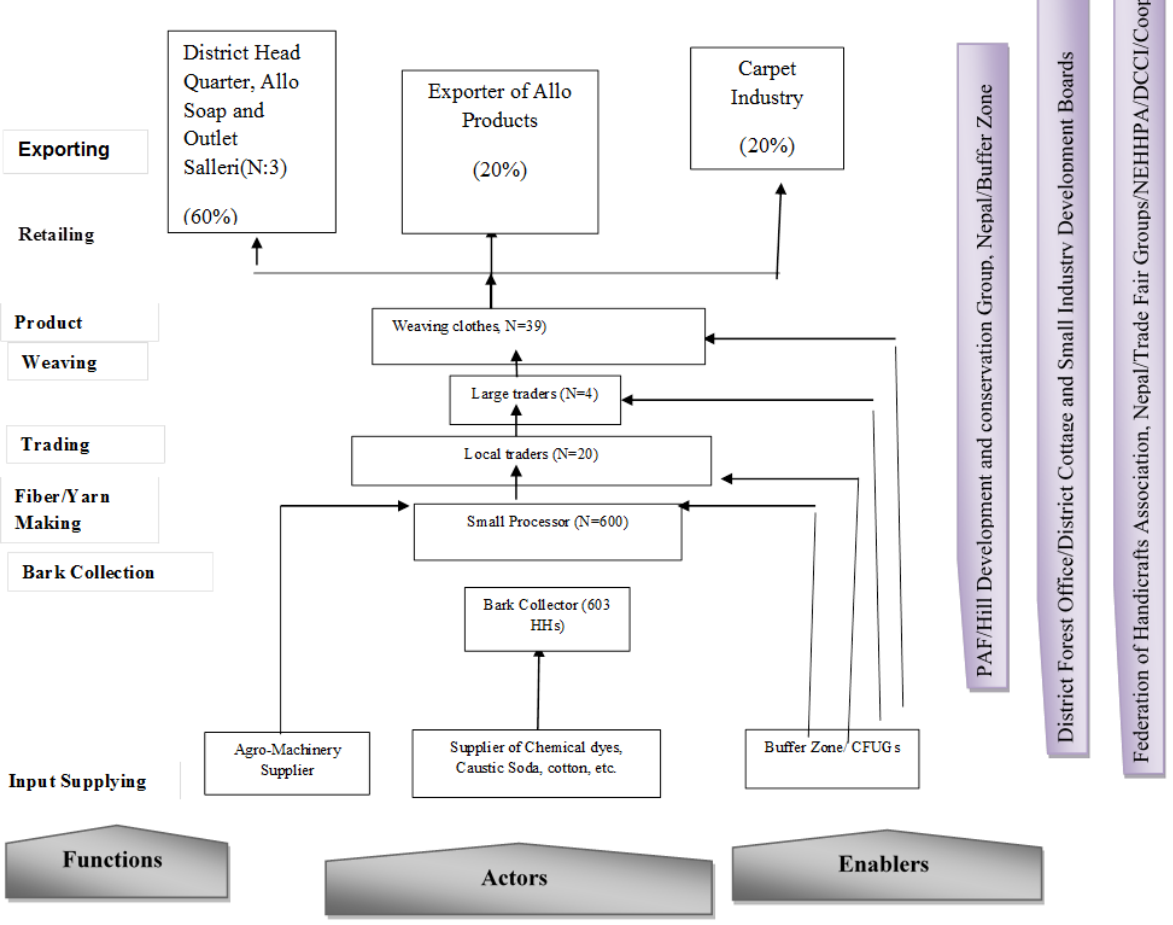

Figure 2. Value chain map of allo in solukhubu district.

1. Input suppliers: Input suppliers are those who provide inputs for the production of Allo Lokta, fiber, threads, clothes, and other various product types. Technical inputs, threads, threads making machines, cloths making machines, etc are the major inputs for Allo enterprises. These are unique types of naturalbased enterprises that have been expanding on commercialscale for a decade. At lokta collection stage and making fiber stage, CFUG members manage the required tools and equipment by themselves. Thread making machines, cloth making machines, and other tools and equipment for further processing stage is managed by Agro-machinery suppliers and manufactures of machinery and equipment at Kathmandu and India. Government agencies and non-governmental agencies provide technical knowledge and inputs to some extent; however, the flow of information and inputs is not satisfactory.

\section{Buffer Zone Forest Group Member/CFUG Member: The} term Buffer Zone/CFUG member refers to a person or his/her family members who have been collecting and selling Allo. The member also protects and manages sustainably in CFUG land. It is observed that $70 \%$ of the Allo crop is collected from private land.

3. Local processors: Allo is processed at the local level for making Allo fiber and Allo threads. These processed products are then sold to local entrepreneurs and local traders.

4. Road-head traders: Those traders who are located at roadhead and collect the goods from farmers are called road-head traders in the value chain. Road-head traders are usually from the local community and conduct the trading activity of various goods including other NTFPs.

5. National Traders: National Traders are the traders who are actively involved in trading Allo fiber, Allo threads, clothes, and other various products of Allo products. They get goods both from local processors and road-head traders. Besides supplying goods to national markets especially to handicraft industries, they also supply to exporters and national processors/ manufacturers. Sometimes national traders directly provide goods to importers in European and American markets.

6. National processors/manufacturers: They are the firms that are engaged in producing fiber, Allo threads, clothes, and various products from Allo cloth such as Coat, Shawl, Shirt, handbag, etc. These products have been trading in national and international markets.

7. Exporters: Exporters are the firms, which export various final products of the Allo plant. Major products of Allo are exported to Europe and America. Various types of fair trade groups and natural products exporters are involved in exporting these products to Europe, America, and Asian markets.

8. Wholesalers: Wholesalers are defined as those who sell the goods to retailers.

9. Retailers: They are the trader who gets goods from wholesalers and sells to end consumers. Retailing shops of handicrafts and departmental stores are the main retailer of Allo products. 
Table 2. Constraints and opportunities of Allo business in different value chain stages.

\begin{tabular}{|c|c|c|}
\hline $\begin{array}{l}\text { Value chain } \\
\text { stage }\end{array}$ & Constraints & Opportunities \\
\hline Input supply & $\begin{array}{l}\text { - No supplier for commercial/ cost } \\
\text { effective tools and equipment for } \\
\text { spinning of Allo threads. } \\
\text { - No well certified technology for } \\
\text { domestication. } \\
\text { - No availability of technology for } \\
\text { disease and paste management of } \\
\text { Allo plant. } \\
\text { - Not enough raw materials for value } \\
\text { addition. } \\
\text { No mentioned in operation plan } \\
\text { about Buffer Zone forest user group/ } \\
\text { CFUG for domestication and } \\
\text { sustainable management. }\end{array}$ & $\begin{array}{l}\text { - Allo spinning machine brought form outside district through } \\
\text { supporting agencies such as CSIDB, PAF, Hill Development and } \\
\text { Conservation Group, Nepal. They are facilitating input supply } \\
\text { through coordination of manufacturing companies. } \\
\text { - NARC and Agriculture and Forestry University (AFU) can } \\
\text { support for research and development of domestication and } \\
\text { disease management. } \\
\text { District forest office, wildlife and forest conservation office are } \\
\text { willing to support for sustainable commercialization of Allo. } \\
\text { These government agencies could support to mention Allo } \\
\text { management in new operation plan. } \\
\text { PAF is involved in whole value chain for commercialization of } \\
\text { Allo based enterprises. }\end{array}$ \\
\hline Production & $\begin{array}{l}\text { - Inventory records of raw materials is } \\
\text { unavailable. } \\
\text { - Allo domestication and sustainable } \\
\text { management of Allo is not present in } \\
\text { CFUGs'operation plan. } \\
\text { - Insufficient financial resource for }\end{array}$ & $\begin{array}{l}\text { - DFO/ National Park and wildlife conservation office can } \\
\text { support the members of CFUG for inventory recording during } \\
\text { operation plan review and new operation plan development. } \\
\text { Through this process, it will be easy to secure permission for } \\
\text { business registration. On top of that, MEs will receive training } \\
\text { opportunities for technical enhancement. }\end{array}$ \\
\hline
\end{tabular}

$$
\text { production and marketing. }
$$

- High cost of production in comparison to neighbor Allo production district, Sankhuwasabha.

- No approved technology for domestication and disease and paste management.

- No human resources and infrastructure (sewing machines, over lock machine, etc) for the production of consumer products such as bag, porches, hat, sandals, etc.

Marketing - Limited access to output marketing actors.

- No regular interaction mechanism between traders and producer groups.

- No transparency mechanism during selling of products.

- No sub-contracting model for the assurance of selling products in larger scale.

Processing - Post harvesting management and local level processing is labor intensive and costly.

Financial services

Infrastructure
- Financial access with only PAF supported cooperatives, which are very limited in number.

- Insufficient credit for doing business.

- No sales outlet of beneficiaries for selling products.

- No tools and equipment available for cost efficient and quality threads production.

- $\quad$ working places
- Allo based products have increased market demand in national and international market.

- Buyer seeks to receive products in large scale.

- Could develop sub-contracting model for assurance of buy back guarantee of products.

- $\quad$ Supporting agencies have been providing training, required tools and equipment to related entrepreneurs. In this regard, entrepreneurs are increasing.

- $\quad$ CSIDB has been supporting technology other things declaration of Allo production pocket area.

- Could increase the linkage with other financial institution.

- NRB and other financial institutions have the provision of wholesale lending which can increase the financial access to PAF supported cooperatives.

- Opportunities to link local federal government to construct infrastructure and places.

- $\quad$ CSIDB provides cost effective technology and other necessary support. 
Enablers and facilitators

In a value chain, the enabler is all chain-specific actors providing regular support services or representing the common interest of the value chain actors. Functions at the enabler level include public research and technology development, agreement on professional standards, promotional services, joint marketing or advocacy, and another support service.

\section{Enablers in production and local processing functions}

For the producers groups, District Forest Office (DFO), Community Organizations, Cooperatives, Federation of Community Users Nepal (FECOFUN), Buffer Zone Forestry User Coordination Committee, Federation of Handicrafts Association, Nepal and various development organizations provide technical and financial assistance to local producers, cooperatives and private sectors for value addition and marketing.
Enablers in trading and export functions

In traders' level, Business Membership Organizations (BMOs) like Nepal Herbs and Herbal Production Association (NEHHPA), Federation of Handicrafts Association, Nepal District Chamber of Commerce and Industries (DCCl) are involved to make this business successful. Agro Enterprise Centre (AEC) works in the area of market development by providing market information, facilitation for market linkages, etc. Similarly, the Trade and Export Promotion Centre (TEPC) assists in the export of goods, support to organize various trade fair and also maintain the export data. At a higher level, the Ministry of Forest and Soil Conservation (MoFC) and Department of Forest (DoF) Federation of Nepalese Chamber of Commerce and Industries (FNCCI), Ministry of Industry, Commerce and Supplies are involved to enable this value chain.

Table 3. SWOT Analysis of Allo and its processed products business.

\begin{tabular}{|c|c|}
\hline Strengths & Weaknesses \\
\hline $\begin{array}{l}\text { - Indigenous skills and culture in Kulung Rai women } \\
\text { communities. } \\
\text { - } \quad \text { Local Communities use their leisure time for doing } \\
\text { - } \text { More based business. } \\
\text { resources. } \\
\text { - Has capacity to produce according to market } \\
\text { demand in quality, design and size. } \\
\text { - No ban or restriction on collection, trade and } \\
\text { export. } \\
\text { Has provision to cultivate to a wider area in CFUG } \\
\text { land, private land and buffer zone. } \\
\text { At present more than } 70 \% \text { Allo bark are harvested } \\
\text { from private land. Local communities did through } \\
\text { cultivation and sustainable management resources. }\end{array}$ & $\begin{array}{l}\text { - No linkage development among producers and buyers. No } \\
\text { - } \quad \text { Producer has no skills for value addition of products from } \\
\text { Allocloths. In addition, there is lack of infrastructure such as } \\
\text { industrial sewing machine, over lock machine, working halls, etc. } \\
\text { - } \quad \text { Lack of knowledge and product diversification. } \\
\text { - } \quad \text { Fixed season for harvesting of raw materials. } \\
\text { - } \quad \text { Constraint government policies and taxation process. } \\
\text { - } \quad \text { Maintaining supply chain and market distribution network is } \\
\text { - } \quad \text { difficult as like Sikki carft (Paras and Varshneya, 2015). } \\
\text { CSIDB, there are only } 6 \text { registered Allo based enterprises in } \\
\text { - Solukhumbu district. } \\
\text { - } \quad \text { Inack of preparation of business plan. } \\
\text { - Producer are still using conventional technology and methods of } \\
\text { production, which are highly inefficient. This restricts their } \\
\text { production capacity, produce low quality of outputs and require } \\
\text { high cost of production. }\end{array}$ \\
\hline
\end{tabular}

\begin{tabular}{l}
\hline Opportunities \\
\hline - $\quad$ PAF and other government agencies are in full \\
support for the commercialization of this business. \\
- $\quad$ menge opportunity to generate income and employ- \\
- $\quad$ Niche market opportunity due to unique qualities. \\
- $\quad$ District forest office, Makalu National Park and wild \\
conservation office are willing to support for \\
cultivation by supporting CFUG to mention in their \\
operation plan. \\
Through coordination with NARC and Agriculture \\
and Forestry University (AFU), commercial cultiva- \\
tion technology and disease and paste management \\
technology will identify.
\end{tabular}

\section{Threats}

- No approve technology has introduced for commercial cultivation.

- Threat to sustainable production of resource.

- Most of the productions are done through traditional technology such as spinning of threads. This technology requires high cost of production than other district. i.e. Sankhuwasabha District.

- Domestic threats in terms of labor issues.

- Misconception about handicraft products being more expensive than conventional products.

- Inadequate advocacy and promotions.

(Sources: FGDs, KII and Field Survey, 2018; Rai and Chapagain, 2014; Paras and Varshneya, 2015). 
Public actors

Ministry of Forest and Soil Conservation (MoFSC) and Department of Forest (DoF): MoFSC facilitates this value chain through the Department of Forest and its districts. It designs a suitable policy for benefiting micro-entrepreneurs and poor CFUG members. Beyond this, it does some regulatory works for the sustainable management of resources and provides a fund to entrepreneurs.

Cottage and Small Industry Development Board: This government agency is under the Ministry of Industry. It supports entrepreneurs especially for registration of enterprises, provides entrepreneurship training, technical training technology access and so on. This government organization also conducts training to Allo entrepreneurs along with training materials.

Trade and Export Promotion Centre (TEPC): TEPC is established under the Ministry of Commerce and Supplies with the objective of promoting foreign trade. This agency supports export promotion through trade fairs, participation in the various program, information dissemination about procedure and others to trading organizations and associations.

Federation of Handicraft Association (FHN), Nepal: This is an association of entrepreneurs involved in handicraft businesses such as Allo, pashmina, bamboo, woolen, artisan, etc. This organization supports entrepreneurs through marketing, connection to the fair trade group, organization of trade fair, advocacy, etc.

\section{Projects/organizations}

Poverty Alleviation Fund: PAF supports MEs through a revolving fund, technical training, marketing support, equipment, entrepreneurship development training, domestication, etc.

Hill Development and Conservation Group Nepal: This is the partner organization of PAF in Solukhumbu District. It supports local entrepreneurs for technology, domestication, marketing, entrepreneurship development, etc.

Nepal Herbs and Herbal Production Nepal (NEHPA): This is a trader's association especially of NTFP. This organization supports Allo entrepreneurs through the management of trade fair, buyback guarantee of products, advocacy, etc.

Constraints and Opportunities Analysis

Constraints and opportunities of Allo business in different value chain stages are given in Table 2.

SWOT analysis for production, marketing, and upgrading of sub-sector

SWOT Analysis of Allo and its processed products business are given in Table 3.
Value chain upgrading strategy of Allo processing

The value chain upgrading strategy of Allo processing is given in Table 4.

Potential Intervention Area for Value chain alliance and financing

Potential intervention areas for value chain alliance and financing are given in Table 5.

\section{Internal and external value chain financing}

At present, the financing resources to this value chain is mainly RF from PAF and PAF supported cooperative. To increase business to this value chain and create more employment opportunities, it is necessary to make financial services accessible to value chain actors. The main area of the capital requirement is marketing, basic infrastructure (building, industrial sewing machine, overlock machine, iron sets for yarn making, thread making machine, press machine, basic materials for fiber making, harvesting tools), disease and paste management, raw materials management, etc (Table 6).

\section{Environmental analysis}

At present more than $70 \%$ of raw materials (Allo bark) are coming from private land in Solukhumbu district. Local communities have been cultivating this crop through their own experience especially from the old plant. After two years of cultivation, it will be ready to get harvested. The sustainable harvesting practice eases the collection of the crop every year. But the main problem lies in the production level due to disease and paste management. Research and development are necessary to approve technology for domestication and disease and paste management. On the other hand, in the CFUG/Buffer Forest area, CFUG members have been cultivating and harvesting Allo. However, there is no mention in the operation plan. From a sustainable point of view, it necessary to conduct resource inventory at the district level, need to review and prepare a new operation plan with mentioning the sustainable management plan of Allo.

\section{Market analysis and strategy}

In Nepal, around 1805 tonnes of Allo bark is harvestable from 55 districts. At present around 150-200 tonnes of Allo yarn/ threads have been producing per year. As it has already mentioned, Allo trading has been generating tentatively NPR 65.94 million trade value per year in Solukhumbu district, if we could support and provide enabling business environment to local communities, the trade value will increase to NPR 1.44 per year. On the other hand, there are a total of 39 micro enterprises (MEs) working for the production of Allo cloths. Their yearly average production is 171 meters. If they are provided with the market assurance, each ME can easily produce 1000 meters per year. As a result, the production will increase as well as employment opportunities at the local level. There are also opportunities to produce consumer-finished products from Allo cloth at the local level. Overall, market penetration is a prerequisite. 
Table 4. Value chain upgrading strategy of Allo processing.

\begin{tabular}{|c|c|c|c|}
\hline Chain level & Context and situation & Key gaps identification & Intervention approaches \\
\hline $\begin{array}{l}\text { Inputs and } \\
\text { services }\end{array}$ & $\begin{array}{l}\text { - Labour intensive work in Allo } \\
\text { processing is thread making. - } \\
\text { MEs have been working } \\
\text { through traditional method. } \\
\text { Producers are harvesting more } \\
\text { than 70\% Allo bark from pri- } \\
\text { vate land. But there is no well } \\
\text { known technology for domes- } \\
\text { tication. They are } \\
\text { suffering from disease and } \\
\text { paste management. } \\
\text { MEs are getting financial }\end{array}$ & $\begin{array}{l}\text { - Lack of suppliers for commer- } \\
\text { cial/ cost effective tools and } \\
\text { equipment for spinning of Allo } \\
\text { threads. } \\
\text { - No well approved technology } \\
\text { for domestication of Allo. } \\
\text { - No technology available for } \\
\text { disease and paste management } \\
\text { for Allo plant. } \\
\text { Not enough raw materials for } \\
\text { value addition. }\end{array}$ & $\begin{array}{l}\text { - Identify and assess tools and } \\
\text { equipment for cost effective } \\
\text { production. } \\
\text { - Conduct R\&D and support for } \\
\text { commercial domestication and } \\
\text { disease and paste management } \\
\text { method. } \\
\text { - Support to prepare business } \\
\text { plan and access financial } \\
\text { services from other financial } \\
\text { institutions. }\end{array}$ \\
\hline
\end{tabular}
services from revolving fund and PAF cooperative.

Production - Around 15 tonnes of dried Allo is harvested every year and traded in Solukhumbu district but there is no proper record mechanism by government institution.

- No identification about stock and assessment for doing yearly harvesting and trade quantity from sustainable point of view.

- High cost of production as compared to neighbor district, Sankhuwasabha district.
Collection/ trading

Processing
- At present, Allo trading generates tentatively NPR. $65,94,000$ trade value per year in Solukhumbu district (through estimated 15 tonnes of Allo bark.)

- Around $70 \%$ of bark is collected from private land.

- $\quad$ Around $50 \%$ of raw materials is traded in neighboring district Sankhuwasabha,

- $\quad$ Production of fiber and thread using traditional method.

- Tools and equipment are not functional.
- No mention of Buffer Zone forest user group/CFUGs' operation plan about the domestication and sustainable management.

- No resource inventory assessment has been done to check the availability of raw materials.

- No Mention of Allo domestication and sustainable management of plan in CFUGs' operation plan.

- Insufficient financial resource for production and marketing.

- High cost of production in comparison to neighboring Allo production district, Sankhuwasabha.

- No approved technology for domestication and disease and paste management.

- No human resources and infrastructure (Sewing machines, over lock machine, etc)for the production of consumer products such as Bag, Porches, hat, sandals, etc

- Insufficient raw materials to increase the production level.

- Around $50 \%$ of raw materials is traded in other district,

- From Allo finished products such as hat, cap, bag, shoes are produced in Kathmandu and these finished products are sold back to Solukhombu district.

- No sufficient market assurance for selling finished products.

- Support technologies are not functional due to low efficiency.

- No technical skills with MEs for commercial operation.
- Support to include sustainable management of Allo in CFUG/ buffer Zone CFUGs's operation plan.

- Inventory of resources should be taken for assessment of yearly production potential in a sustainable manner

- Support and assess technology and management to reduce cost of production especially for thread making and cloth production.

- Provide technical training and basic infrastructure at local level from cloth industry in coordination with new federal structure, and private sectors.

- Encourage and support MEs to produce value addition of products.

- Make M4P mechanism for assurance of market.

- Assess and support commercial viable technology to reduce cost of production.

- Train and encourage using new technology to reduce cost of production.

- $\quad$ Conduct R\&D to introduce new technology to reduce cost of production and improvement of quality. 
Table 4. Continued...

\begin{tabular}{|c|c|c|}
\hline $\begin{array}{l}\text { End } \\
\text { market }\end{array}$ & $\begin{array}{l}\text { - Mostly coat cloth is traded in } \\
\text { Solukhumbu district. } \\
\text { Finish products are prepared } \\
\text { in Kathmandu and traded in } \\
\text { domestic market as well as } \\
\text { exported to foreign market. }\end{array}$ & $\begin{array}{l}\text { - Limited access to output market- } \\
\text { ing actors. } \\
\text { - No regular interaction mecha- } \\
\text { nism between traders and } \\
\text { producer groups. } \\
\text { - No transparency mechanism dur- } \\
\text { ing selling of products. } \\
\text { - No sub-contracting model for the } \\
\text { assurance of selling products in } \\
\text { large scale. }\end{array}$ \\
\hline
\end{tabular}

Backward - Limited access and disseminalinkage

Forward linkage

Vertical integration

- $\quad$ Limited B2B linkage.

- No transparency in sales and marketing activities.

- Unhealthy competition among buyers. tion for input supply such as technology, tools and equipment.

- Limited access to financial institution.

$\bullet$

- Producers are not being able to compete in market due to lack of access to technology that reduces the cost of production.

- Insufficient capital with different value chain actors to expand their business.

- Producers do not have information about the exact market channel.

- No platform to sale their products through open interaction

- Producer groups have no end market actors.
- Access new technology to grow and sustain business.

- Make financial resources accessible to different value chain actors to expand their business.
Horizontal integration
- Raw material harvesting, fiber production, thread production and cloth making work are done in single places to some extent.

- No value addition from Allo clothes
- $\quad$ Limited financial resources.

- Lack of entrepreneurship

- No technical skills and infrastructure for value addition in desired scale.
- Financial access and introduce $\mathrm{m} 4 \mathrm{p}$ approach for market assurance of products.

- Technical training and manage infrastructure through coordination of new federal structure.

- Regular business backstopping and entrepreneurship development to increase business and value addition at local level.
- Limited relationship among producer group within district through PAF and limited relationship with adjoining district Sankhuwasabha.

- No producer association in the district.

- Limited relationship between district level traders and other traders.
- No platform for regular interaction mechanism for value chain actors.

- No exchange of technology mechanism to reduce cost of production, and marketing
- Build relationship with other actors for experience sharing, technology and marketing.

- Form association and their institutional development.

(Sources: FGDs, KII and Field Survey, 2018). 
Table 5. Potential intervention area for value chain alliance and financing.

\begin{tabular}{|c|c|c|c|c|}
\hline $\begin{array}{l}\text { VC } \\
\text { Functions }\end{array}$ & Area of interventions & $\begin{array}{l}\text { Key partners and } \\
\text { alliances }\end{array}$ & $\begin{array}{l}\text { Types of } \\
\text { Financing } \\
\text { Required }\end{array}$ & $\begin{array}{l}\text { Potential } \\
\text { revenue } \\
\text { generation for } \\
\text { PAF }\end{array}$ \\
\hline $\begin{array}{l}\text { Raw } \\
\text { material } \\
\text { Collection \& } \\
\text { Input supply }\end{array}$ & 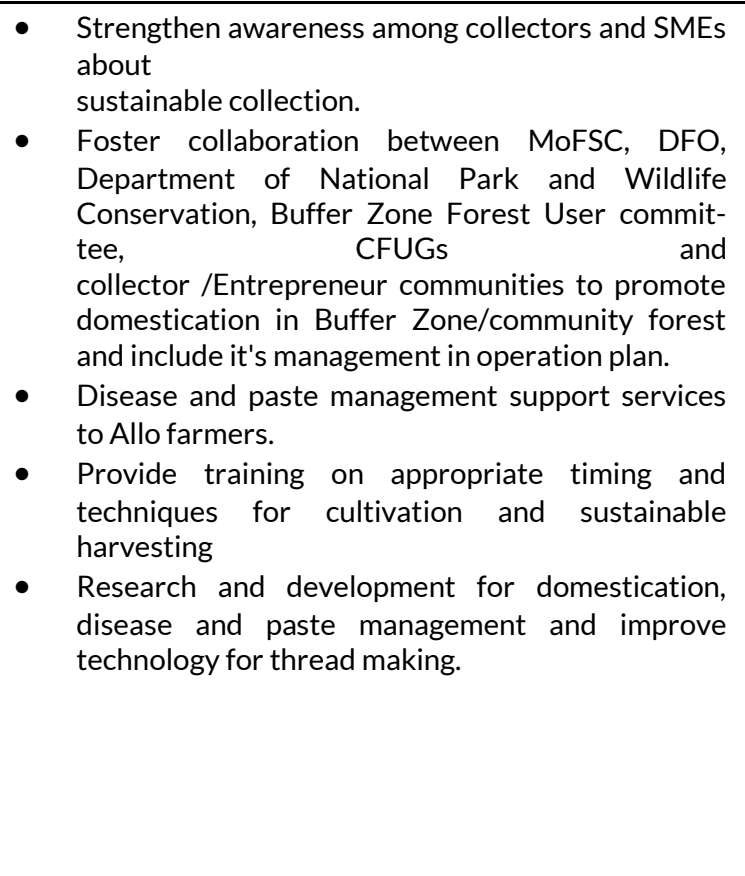 & $\begin{array}{l}\text { - } \text { Buffer Zone } \\
\text { CFUGs } \\
\text { Collector, } \\
\text { CFUGs } \\
\text { - } \text { Agriculture } \\
\text { and } \\
\text { Forestry } \\
\text { University } \\
\text { (AFU) } \\
\text { Department } \\
\text { of } \\
\text { Agriculture } \\
\text { Tools } \\
\text { Equipment's } \\
\text { suppliers } \\
\text { Financial } \\
\text { Institutions } \\
\text { DoF } \\
\text { Department } \\
\text { of National } \\
\text { Park and Wild } \\
\text { Life } \\
\text { Conservation }\end{array}$ & $\begin{array}{ll}\text { - } & \text { Technical } \\
\text { - } & \text { Assistance } \\
\text { Research }\end{array}$ & $\begin{array}{ll}\text { - } & \text { TA } \\
\text { service fee, } \\
\text { Loan } \\
\text { brokerage } \\
\text { fee } \\
\text { - Support } \\
\text { Activities }\end{array}$ \\
\hline $\begin{array}{l}\text { Raw } \\
\text { material } \\
\text { Processing }\end{array}$ & $\begin{array}{l}\text { - Facilitate and Improve the supply of quality inputs } \\
\text { tools/equipment's to Collector/Allo product pro- } \\
\text { ducers and SMEs in timely manner } \\
\text { - Enhance the capacity of primary } \\
\text { processors (fiber production, thread production) } \\
\text { with modern tools \& equipment to improve pro- } \\
\text { cessing and production } \\
\text { techniques that ensures quality. } \\
\text { - Facilitate and support SMEs for enterprise } \\
\text { registration in coordination with local federal } \\
\text { government structure, CSIDB and } \\
\text { increase to access a the } \\
\text { services for commercialization of their enterpris- } \\
\text { es/business. }\end{array}$ & $\begin{array}{ll}\text { - } & \text { Collectors } \\
\text { - } & \text { Tools/ } \\
& \text { Equipment's } \\
& \text { Manufacturer } \\
\text { - } & \text { FHAN } \\
\text { - } & \text { CSIDB }\end{array}$ & $\begin{array}{l}\text { - Technical } \\
\text { - } \text { Assistance } \\
\text { Co invest- } \\
\text { ment (Grants } \\
\text { \& Loans) for } \\
\text { input supply } \\
\text { business }\end{array}$ & $\begin{array}{l}\text { TA service } \\
\text { fee for } \\
\text { trainings \& } \\
\text { Enterprises } \\
\text { registra- } \\
\text { tion , Loan } \\
\text { brokerage, } \\
\text { Commission } \\
\text { on Business } \\
\text { linkages for } \\
\text { tools \& } \\
\text { equipment's }\end{array}$ \\
\hline $\begin{array}{l}\text { Product } \\
\text { Design \& } \\
\text { Development }\end{array}$ & $\begin{array}{l}\text { - Capacitate and co-invest SMEs/producers to pro- } \\
\text { duce quality products, value addition, diversified \& } \\
\text { competitive } \\
\text { following sustainable design trends as per consum- } \\
\text { er demand (consumer product at local level such } \\
\text { as bag, purse, cap, hat, shoes, etc). } \\
\text { Support for technical and advisory services to Allo } \\
\text { manufacturers on quality management, cost re- } \\
\text { duction and business management practices to } \\
\text { improve } \\
\text { competitiveness. } \\
\text { Encourage artisans /SMEs to participate in coop- } \\
\text { eratives so that they can better access } \\
\text { business development services (BDS) and platform } \\
\text { for marketing their product. } \\
\text { Facilitate and enhance capacity of Allo product } \\
\text { manufacturer /artisans on financial management } \\
\text { and marketing of their products through sales } \\
\text { outlet and trade fair /exhibition } \\
\text { Facilitate and support to develop common facility } \\
\text { center at specific location } \\
\text { Alliance with primary processors to secure the } \\
\text { availability of quality raw materials }\end{array}$ & $\begin{array}{ll}\text { - } & \text { Product man- } \\
\text { ufacturers } \\
\text { - } & \text { Tools/ } \\
\text { Equipment's } \\
\text { Manufacturer } \\
\text { - } \quad \text { Service } \\
\text { Providers } \\
\text { - } \quad \text { FHAN } \\
\text { - } \quad \text { CSIDB }\end{array}$ & $\begin{array}{l}\text { - Technical } \\
\text { Assistance for } \\
\text { capacity } \\
\text { building, } \\
\text { Institutional } \\
\text { development } \\
\text { \& Business } \\
\text { Management } \\
\text { Co invest- } \\
\text { ment( Grants } \\
\text { \& Loans) for } \\
\text { product } \\
\text { Manufactur- } \\
\text { ers to adopt } \\
\text { new } \\
\text { technology / } \\
\text { design and to } \\
\text { participate in } \\
\text { trade fairs } \\
\text { Co-financing } \\
\text { storage facili- } \\
\text { ties \& Market } \\
\text { Centre with } \\
\text { product man- } \\
\text { ufactures }\end{array}$ & $\begin{array}{l}\text { - TA service } \\
\text { fee, Loan } \\
\text { Brokerage } \\
\text { fee, } \\
\text { Commission } \\
\text { fee for } \\
\text { brokering } \\
\text { business \& } \\
\text { linkages \& } \\
\text { Service } \\
\text { linkages }\end{array}$ \\
\hline
\end{tabular}


Table 5. Continued.

\begin{tabular}{|c|c|c|c|c|}
\hline $\begin{array}{l}\text { End market } \\
\text { (national and } \\
\text { international) }\end{array}$ & $\begin{array}{l}\text { - Strengthen SMEs for collective marketing } \\
\text { and facilitate their business relationships } \\
\text { with buyers at local, regional and internation- } \\
\text { al markets. } \\
\text { - Make regular interaction mechanism } \\
\text { between producers and market actors. } \\
\text { - Facilitate buy back guarantee and contracts } \\
\text { between Allo manufacturers and buyers/ } \\
\text { exporters to establish and develop positive } \\
\text { relationships. } \\
\text { Conduct Market research of Allo products } \\
\text { both at national and international level. }\end{array}$ & $\begin{array}{ll}\text { - } & \text { Product } \\
\text { - } & \text { panufacturers } \\
& \text { SMEs } \\
\text { - } & \text { Buyers } \\
\text { (institutional } \\
\text { as hotels, } \\
\text { offices \& indi- } \\
\text { vidual) } \\
\text { Exporters } \\
\text { - TEPC } \\
\text { - FHAN }\end{array}$ & $\begin{array}{l}\text { - TA, Co } \\
\text { investments } \\
\text { (Grants \& } \\
\text { Loan), } \\
\text { Research \& } \\
\text { Studies } \\
\text { - Market } \\
\text { promotion } \\
\text { support } \\
\text { activities }\end{array}$ & $\begin{array}{l}\text { - TA, and } \\
\text { Commission } \\
\text { through } \\
\text { brokering } \\
\text { business } \\
\text { linkages }\end{array}$ \\
\hline $\begin{array}{l}\text { Service } \\
\text { Provision }\end{array}$ & $\begin{array}{l}\text { - Strengthen technical service providers and } \\
\text { facilitate their linkages with product } \\
\text { manufactures. } \\
\text { - Provide technical assistance related to } \\
\text { institutional development, market manage- } \\
\text { ment, market information dissemination, and } \\
\text { gender empowerment. } \\
\text { - } \text { Facilitate Business to Services linkages. } \\
\text { - Develop new and appropriate financial } \\
\text { products to reach smallholder producers. } \\
\text { Provide financial access to meso level market } \\
\text { actor for greater transaction of products. }\end{array}$ & $\begin{array}{ll}\text { - } & \text { FHN } \\
\text { - } & \text { Financial Insti- } \\
\text { tutions } \\
\text { commercial / } \\
\text { Banks } \\
\text { - Technical, } \\
\text { Business } \\
\text { Service Provid- } \\
\text { ers } \\
\text { Producers / } \\
\text { SMEs }\end{array}$ & $\begin{array}{l}\text { - Technical } \\
\text { - Assistance } \\
\text { - Grants and } \\
\text { Loans }\end{array}$ & $\begin{array}{l}\text { TA service } \\
\text { Fee, Loan } \\
\text { Brokerage } \\
\text { fee, } \\
\text { Commission } \\
\text { through } \\
\text { brokering } \\
\text { service } \\
\text { business } \\
\text { linkages }\end{array}$ \\
\hline
\end{tabular}

(Sources: FGDs, KII and Field Survey, 2018).

Table 6. Financial Institutions and Government Department to promote value chain alliances and finance in Allo Value Chain.

\begin{tabular}{|c|c|c|}
\hline Financial Institutions & Government Department & Private Sector \\
\hline Commercial Bank & $\begin{array}{l}\text { All department under Ministry of Forest and Soil } \\
\text { Conservation and Ministry of Industry, Commerce } \\
\text { and Supplies. }\end{array}$ & $\begin{array}{l}\text { FNCCI particularly Agro Enterprise } \\
\text { Center }\end{array}$ \\
\hline Development Banks & $\begin{array}{l}\text { Cooperatives Department, Company registrar Of- } \\
\text { fice }\end{array}$ & Agro-SMEs \\
\hline Micro-finance Institutions & $\begin{array}{l}\text { Municipalities and Rural } \\
\text { (GaunPalika) }\end{array}$ & Traders and aggregators \\
\hline Cooperatives & Agriculture and Forestry University Rampur & Federation Handicraft Association \\
\hline None-Life Insurance Companies & $\begin{array}{l}\text { CTEVT and its affiliated agriculture training center } \\
\text { Credit Information Bureau }\end{array}$ & NEHHPA \\
\hline
\end{tabular}

Table 7. Cost advantage of the proposed value chain Allo sub-sector.

\begin{tabular}{|c|c|c|c|c|c|}
\hline Aspects of Allo Sub-sector VCD Potentiality & Year 1 & Year 2 & Year 3 & Year 4 & Year 5 \\
\hline Income generation (Annual) (NPR in Million) & 15.7 & 31.4 & 47.1 & 62.8 & 78.5 \\
\hline Initial Investment/loan fund required (Annual) (NPR in Million, both $\mathrm{FC}+\mathrm{OC}$ ) & 13.1 & 26.2 & 39.3 & 52.4 & 65.5 \\
\hline $\begin{array}{l}\text { Insurance premium cost required (Investment based) (NPR in Million) Not } \\
\text { applicable in Allo VC }\end{array}$ & 0.0 & 0.0 & 0.0 & 0.0 & 0.0 \\
\hline Available capital fund (RF) from COs to be mobilized (NPR in Million) & 3.9 & 7.8 & 11.7 & 15.6 & 19.5 \\
\hline Loan fund required from external financial institutions (NPR in Million) & 9.2 & 18.4 & 27.6 & 36.8 & 46.0 \\
\hline No. of Self Employed/No. of Entrepreneurs & 78 & 156 & 234 & 312 & 390 \\
\hline No. of employment generated (seasonal) & 78 & 156 & 234 & 312 & 390 \\
\hline Allo cloth production (in meter) & 31395 & 62790 & 94185 & 125580 & 156975 \\
\hline $\begin{array}{l}\text { No. of potential SMEs to be created for value chain (processing, marketing and } \\
\text { product diversification) }\end{array}$ & 6 & 13 & 19 & 25 & 31 \\
\hline No. of employment to be generated by proposed SMEs & 63 & 126 & 188 & 251 & 314 \\
\hline $\begin{array}{l}\text { Total employment generation including enterprises and SMEs from PAF } \\
\text { intervention }\end{array}$ & 225 & 450 & 675 & 900 & 1125 \\
\hline Return to Investment (Rol)\% & & & & & 19.9 \\
\hline $\begin{array}{l}\text { Market Share (\%) (Only few HHs involved in product making by PAF initiative in } \\
\text { Nepal and after three year, out of total production PAF intervention will share } \\
40 \% \text { at national level) }\end{array}$ & & & & & 40 \\
\hline No. of $\mathrm{HH}$ members benefited & 733 & 1466 & 2200 & 2933 & 3666 \\
\hline $\mathrm{B} / \mathrm{C}$ ratio & & & & & 1.2 \\
\hline Commission to PAF (from loan brokerage and insurance linkage services) & 0.2 & 0.4 & 0.6 & 0.7 & 0.9 \\
\hline $\begin{array}{l}\text { Revenue generated by government (CF), Fee, Royalty, Private Sector/Public } \\
\text { including tax (NPR in million) }\end{array}$ & 1.0 & 2.1 & 3.1 & 4.2 & 5.2 \\
\hline
\end{tabular}


Table 8. Assumption notes.

\begin{tabular}{|c|c|}
\hline Assumption Notes & No. \\
\hline \multicolumn{2}{|l|}{ Allo enterprises scheme basic features: } \\
\hline Total Allo small business enterprises in PAF pocket area of Solukhambu (No. HH) & 39 \\
\hline Allo bark collection and selling $\mathrm{HH}$ s of $\mathrm{CO}$ members to enterprise & 603 \\
\hline Annual Allo cloths production and sale by each enterprise per year at current situtation (in meter) & 161 \\
\hline Potential and proposed Allo cloths production and sale by each enterprise per year (in meter) & 403 \\
\hline Average current market price per meter Allo Cloth (NPR/number) & 500 \\
\hline $\begin{array}{l}\text { Potential Allo based enterprises within } 5 \text { years (Numbers) in Solukhumbu, Magdhi, Gorkha, Dailekh, Sankhuwasava) } \\
\text { (10 times of existing } 39 \text { enterprises) }\end{array}$ & 390 \\
\hline Allo barks require to make Allo thread $(\mathrm{kg})$ & 3.2 \\
\hline Annual Allo bark require for each enterprise $(\mathrm{kg})$ & 13417 \\
\hline Production of Allo cloths by one kg of thread (in meter) & 6 \\
\hline Cost for Allo bark (NPR/kg) & 200 \\
\hline Cost for producing Allo thread (NPR/kg) & 1140 \\
\hline Price of Allo thread (NPR/kg) & 1200 \\
\hline Total thread require for each enterprise annually $(\mathrm{kg})$ & 67 \\
\hline Additional Cost of cotton/woolen thread for making 1 meter Allo cloth (NPR) & 77 \\
\hline Labor cost and other cost to make 1 meter Allo cloth (NPR) & 150 \\
\hline Cost for making 1 meter Allo cloth (NPR) & 417 \\
\hline Market price of Allo cloth per meter (NPR) & 500 \\
\hline Annual investment/cost require for each enterprise (NPR) & 167843 \\
\hline Annual revenue /enterprise (NPR) & 201250 \\
\hline No. of employment generated (seasonal) & 403 \\
\hline Total annual revenue to be generated from 390 Allo Entrepreneurs (NPR in Million) & 78.5 \\
\hline Estimated No. of total annual production in Allo Enterprises in $5^{\text {th }}$ years (Meter) & 156,975 \\
\hline Market share \% & 0 \\
\hline Total annual investment to be required in 5th Year (NPR in Million) & 65.5 \\
\hline Available capital fund (RF) from Cost to be mobilized (NPR in Million) [@NPR 50000/CO member] & 19.5 \\
\hline Loan fund to be required from external financial institutions (NRs. Million) & 46.0 \\
\hline Insurance (Investment based) (NRs. In Million) in Allo product scheme not applicable & 0.0 \\
\hline Total annual investment required in 5th year (NRs. In Million) & 46.0 \\
\hline $\begin{array}{l}\text { No. of potential SMEs to be created for value chain (processing, marketing and product diversification) (@5000 mt cloth } \\
=1 \mathrm{SME}=\text { Year flow) }\end{array}$ & 31 \\
\hline No. of employment to be generated by proposed SMEs & 314 \\
\hline Total employment generation including enterprises and SMEs from PAF intervention & 314 \\
\hline Revenue generated by government (CF), Fee, Royalty, Private Sector/Public including tax (NPR in million) & 5.2 \\
\hline
\end{tabular}

(Sources: FGDs, KII and Field Survey, 2018).

Gender integration in value chain development

Allo cultivation is a labor-intensive and women-friendly business. There are more than $80 \%$ of women involved in the raw material collection, fiber production, thread production, and cloth production. And men are mostly involved in the transportation of raw materials and marketing finished products. It has become one of the major sources of income to that $80 \%$ of women utilizing their leisure time to this business. In order to attract more women to this business, the value addition of Allo clothes could be done which creates more opportunities. In addition, technical training, management of basic infrastructures such as industrial sewing machines, overlock machines, more financial access and regular business backstopping could also create a positive atmosphere to integrate more women and DAG. Thus, while promoting alliances Table 5 provides the actors or enablers that help to promote value chain alliances and finance in Allo Value Chain.
Conclusions and recommendations

The exploitation rate of Allo in the study area has been affecting the availability and sustainability of raw material in the natural habitat. The situation indicates the need for sustainable management through domestication and proper harvesting technique. There is a need for improved processing techniques for cost-effective and environmental points of view. Exploring marketing channels of overseas markets for fashionable products is necessary to sustain the enterprise and enhance income generation. Research and development works should focus on domestication, cultivation, regeneration, disease and paste management and sustainable harvesting along with appropriate processing and spinning techniques for better utilization of Allo. As Allo cultivation may be combined with community forestry programs as an under-story crop, following research would help to promote it. 
- Identify different types/ varieties of Allo plant and fiber yields.

- Need to know the effects of various growing conditions and harvesting practices on fiber quality and quantity, so that optimum conditions can be employed.

- Need to investigate ways in which Allo might usefully find a place within existing farming and forestry system.

Following areas of intervention are recommended for sustainable Allo value chain development in Nepal:

- Allo cultivation: Support Allo cultivation in CF buffer zone and private land. There is a need to develop and establish technology for commercial cultivation

- Technical support: Training, workshops, demonstration tour package, weaving, and fiber production technique can help to upgrade their (local people) skills for the Allo profession.

- Disease and paste management: Farmers are suffering from disease during cultivation and production. It is necessary to develop technology for disease and paste management.

- Policy: In spite of the large volume of harvesting and trade, there is no inventory of resources. On the other hand, there is no mention of sustainable management of resources in CFs' operation plans. For this purpose, it is necessary to do inventory and revision of the operation plan of CFUG/ Buffer zone CFUG.

- Advertisement: Advertisement could be the medium to increase the familiarity or popularity of Allo products among local and national customers. It could increase trade in all over Nepal and abroad.

- Accessible Extra Entities: Extra entity's supplies can help those manufacturers who are not getting extra profit from the business as these materials increase product value.

- Financial Access: Financial access is a prerequisite for sustainable expansion of the business. It is necessary to increase financial access to value chain actors through the management of wholesale lending to MFI and linkage to development and commercial banks.

\section{ACKNOWLEDGEMENTS}

This study was conducted with the financial support from the Poverty Alleviation Fund (PAF) Nepal/World Bank. I would like to thank Dr. Yam Bahadur Thapa, Mr. Nahakul KC and Rishi Ram Kattelfor for their technical support for the Allo value chain analysis and preparing this manuscript. This report will boost understanding and be helpful to design future strategies in this sector. Last but not the least, I would like to express my gratitude to Mr. Krishna Datta Bhatta, Programme Coordinator as Client's Coordinator and the entire technical expert team for their hard work and dedication for making this a successful project.
Abbreviations and Acronyms

AEC: Agro Enterprise Center; AFU: Agriculture and Forestry University; ANSAB: Asia Network for Sustainable Agriculture and Bioresources; B2B:Business to business; CFUG: Community Forestry User Group; CF: Community Forest; CO: Community Organization; DAG: Disadvantage Group; DCCI: District Chamber of Commerce and Industry; DCC: District Coordination Committee; DFO: District Forest Office; DI: Department of Industry; DNPW: Department of Department of National Park and Wild Life; FECOFUN: Federation of Community Forestry Users, Nepal; FGD: Focus Group Discussion; FNCCI: Federation of Nepalese Chambers of Commerce and Industry; HR: Human Resource; MEDEP: Micro-Enterprise Development Programme; MFI: Micro Financial Institution; ME: Micro Entrepreneur; MIS: Marketing Information System; MOFSC: Ministry of Forest and Soil Conservation; M4P : Making Markets Work for the Poor; MSFP: Multi Stakeholder Forestry Programme; NARC: Nepal Agricultural Research Council; NEHHPA: Nepal Herbs and Herbal Production Association; NRB: Nepal Rastra Bank; NTFP: Non-Timber Forest Products; PAF: Poverty Alleviation Fund; R\&D: Research and Development; RM: Rural municipality; VCA: Value Chain Approach; VCD: Value Chain Development; WWF: Worldwide Fund for Nature.

Open Access: This is an open access article published under the terms and conditions of Creative Commons AttributionNonCommercial 4.0 International License which permits noncommercial use, distribution, and reproduction in any medium, provided the original author(s) if the sources are credited.

\section{REFERENCES}

ECARDS-Nepal/MSFP (2015). Local value chain analysis of selected NTFPS in Ramechhap, Khotang and Okhaldhunga Districts.

MEDEP (2010). Value Chain Analysis of Allo. Value chain series 1. Value Chain Based Approach to Micro-Enterprises Development. Micro-Enterprise Development Programme.

MOAC (2011). A report on value chain analysis of ginger subsector in Nepal. Government of Nepal, Ministry of Agriculture and Cooperative (MOAC), High Value Agriculture Project in Hills and Mountain Area (HVAP).

MOFSC (2014). Value Chain Designing of Allo of Panchase Protected Forest Area.

MSFP (2014). Value Chain analysis of selected Forest Based Products of Rapti Area, Multi-Stakeholder Forestry Programme (MSFP), Rupantaran Nepal, April 2014.

Ojha, H., Subedi, B. and Dangal, S.P. (2000). Assessment and sustainable harvesting of Non- Timber Forest Products: Some initiatives in community forestry in the hills of Nepal. Asia Network for Sustainable Bioresources (ANSAB), Kathmandu, Nepal.

Paras, M.K. and Varshneya, G. (2015). Sikki natural fibres handicrafts marketing challenges and opportunities. Industry Articles, Accessed from https://mafiadoc.com/sikki-natural-fibre-handicrafts-marketing-challenges_59cbff2f1723dd7a770cbfa9.html

Paudel, D. and Rosset, C. (1998). What Hanuman Brought was Not Only 'Jadibuti, Nepal Swiss Community Forestry Project, Kathmandu, Nepal.

Polunin, O. and Stainton, A. (1984). Flowers of the Himalaya. Oxford University Press.

Pyakurel, D. and Baniya, A. (2011). Impetus for Conservation and Livelihood support in Nepal. A Reference Book on Ecology, Conservation, Product Development and Economic Analysis of Selected NTFPs of Langtang Area in the Sacred Himalayan Landscape. World Wildlife Fund (WWF) Nepal, pp. 35-41.

Rai, J.K. and Chapagain, S.P. (2014). Value chain analysis of forest products in Koshi Hill districts of Nepal: challenges and opportunities for economic growth. ForestAction Nepal and Rural Reconstruction Nepal, Kathmandu, Nepal. 